Island Studies Journal, Vol. 1, No. 2, 2006, pp. 183-200

\title{
Warm versus Cold Water Island Tourism: A Review of Policy Implications
}

\author{
Godfrey Baldacchino \\ Canada Research Chair (Island Studies) \\ University of Prince Edward Island \\ Charlottetown, PEI, Canada \\ gbaldacchino@upei.ca
}

\begin{abstract}
Not sun, sea, sand but ice, isolation, indigenous people: the critical exploration of extreme tourism in cold water locations has barely started. Cold water island locations tend to have harsh, pristine and fragile natural environments, characterized by wide open spaces. They become contexts for an exceptional and expensive form of vigorous, outdoor, adventure or cultural tourism, and direct encounters with nature. The nature and practices of the tourism industry suggest a more sustainable form of island tourism, very different from what is experienced on the warm, tropical and exotic island stereotype.
\end{abstract}

This paper critically reviews some of the salient contrasts between the 'hot' and 'cold' versions of island tourism. It discusses how, on many 'cold water' island locations, sound strategic management, limited civilian 'buy in', low populations and an absence of pluralism in political life, can conspire with climate and relative inaccessibility to limit tourism to a small scale, lowimpact industry with a relatively high, locally-retained value added. Some 'warm water' islands are trying to follow this model for tourism development, with mixed results.

Keywords: 'cold water' islands, 'warm water' islands, island studies, island tourism, Seychelles, St Barths, Galápagos

Copyright (c) 2006 Institute of Island Studies, University of Prince Edward Island, Canada.

\section{A Double Scene Setting}

This paper starts with two pieces of autobiographical prose. They represent recollections based on two actual 'island tourism experiences', one in cold Iceland and the other in warm Barbados. The extracts are not diary entries, but written specifically with a view to illustrate the arguments raised in this paper, and particularly to support the attempt to conceptualize a distinction between cold water and warm water island tourism. 
It had been a cold, humid, grey day in late September. It was pitch dark by the time I arrived with colleagues at the Blue Lagoon after an hour's coach drive through barren and desolate country out of Reykjavik; a light drizzle was still falling. The temperature was just around the freezing point. We were met by plumes of white smoke, and a dull industrial noise, reminding us that we had arrived at a power plant, with a recreational component which we were about to sample as just an ingenious diversion. I struggled to convince myself that this would be a great and unique sensory experience, fighting my strong misgivings about having accepted to come.

Once registered and given towels and swimming trunks, there was no turning back. Plucking courage from each other, our jokes were probably betraying our nervousness at an oncoming experience the likes of which we had never had before. Having ditched my clothes and donned my swimming gear, I was getting goose pimples even at the very thought of venturing out into the unforgiving Icelandic cold.

I reached what appeared to be an internal, heated swimming pool, but which had a low archway leading to the pitch dark outside space. Nothing could be seen to maintain the level of surprise. Wading in shallow warm water, I drifted begrudgingly towards the archway, lowered my head, and found myself in a much colder space. I was outside. My body shivered, unsure of how to react, and what to expect. Instinctively, I crouched in the warm water, and worked myself further out, away from the exit.

Soon, I got the hang of it. Drifting lazily in the heated pool of mineral rich water, the body could be exposed to varying degrees of cold, depending on how much of it was raised above the surface of the water. The effects of the water on my body were those of soothing and balming, a welcome massage lifting tiredness and in its place charging the body with energy. I could shock my body via a managed exposure to the cold air - as in an abrupt standing up movement, albeit for a few seconds - which would provide an instantaneous numbing sensation. A sauna was also available off on a side, to send the body into a different mode of relaxation and muscular release. Different levels of temperature could thus be felt, with the cold Icelandic air hovering threateningly above. I shared these experiences with my colleagues in the pool, and they with me. It was as if I were in a cocoon, a bubble of safe thermal energy, yet in control of how far I wanted to stay protected and insulated.

I have no idea how long I spent playing around with temperatures. It was soon time to head back, through the same archway, into the wombs of the building, showering off and then buying some health product souvenirs to take home. I felt energized yet relaxed heading back to Reykjavik: at peace with myself, enjoying a sense of cleanliness and internal peace. 
It was warm, just too warm, even though it was March. The ceiling fan was on all the time. The air-conditioned units of the flats next door were working at full blast, and my ceiling fan was also being kept on in order to drown their intrusive noise. My second day in Barbados was as warm and sweltering as the first. The conference business had been concluded and I found myself in my hotel room with an hour to spare before I had to prepare for dinner. I placed my wallet into the safe, got into my trunks and T-shirt, grabbed a towel and headed down to the hotel's beach concession. There at least, close to the beach, a breeze should help me to feel better and less fatigued.

It had been, like the day before, a warm sunny cloudless day, $30^{\circ}$ Celsius. The sun was already unforgiving by 8 a.m. Other than cold drinks, the beach offered the only available reprieve, whether during the day (with sun-worshippers occasionally dipping their bodies into the shallow sea) or during the night when beach parties loudly blared the local version of reggae and familiar disco tunes.

Coming to the beach, I headed for one of the few loungers that was not occupied by sunworshippers, located under the de rigueur palm tree. I took off sandals and vest, deposited my towel (in which I hid my apartment key) and walked to the water. It was warm but pleasant. I waded out to about 3 feet of water, feeling broken pieces of coral under my feet. Just beyond were sharp outlines of the reef, indicating danger and the wisdom of remaining close to shore. Of course, that meant that swimming was not possible. I waded for a few minutes, enjoying the breeze, the spray of the waves lowering and raising my body with their comings and goings, remembering not to look towards the burning sun. I was slightly apprehensive, since I wanted to cast a regular eye to my clothes and towel, just in case there would be petty thieves around. Returning to my lounger, I sat down and closed my eyes, listening to the waves crashing on the shore, and to the occasional bird song. The interplay of the sun and the fronds of the overhanging palm tree cast a mix of light and shadow over my face. Soon, I manoeuvred past the bar, and up the steps to my room, taking a shower (the third in the day?) and preparing to head for dinner. I had gone to the beach to feel the breeze, and for want of not having anything else to do, but also to be able to say that I had at least 'swam' once in Barbados. Been there, done that. It is, somehow, the proper thing to do once there.

\section{Experiences Apart}

The two experiences showcased in the text boxes above are not necessarily typical of visitor experiences. Readers can also accuse me of having doctored my experiences, and more so their description, in order to score deliberate points. There may have been other days in Barbados when I had more time, was more relaxed, and which I enjoyed more; just as I may have had other days in Iceland when I simply couldn't take the cold summer days and their interminable "midnight sun" that made sleeping difficult. Nor am I your typical tourist, or perhaps not even a tourist at all.

Yet, the two factual, auto-biographical narratives are both by the author of this paper. Granted their subjective bias, they (attempt to) portray some of the experiences of warm water versus cold water tourism. In the all-too-common warm water environment, the setting is almost 


\section{G. Baldacchino}

oppressive; the body lethargized; the obligation to play tourist and go through the expected motions is strong. In these places, the tourism industry dominates society at large; space is at a premium; staged authenticity is rampant - evident in the cheap nature of most souvenirs, manufactured in Asia - and the natives can only be obligingly happy. Hedonism - pleasure to the highest good - translates as wild, wanton, excess heat, noise, food and drink. Much activity takes place in or near the water.

In sharp contrast, in the cold water environment, open water is not appealing - its temperature may even be life-threatening - other than in the rare, insulated environments like the Blue Lagoon described above. Indeed, the Blue Lagoon is the exception that justifies the rule: beaches on cold water islands may not be accessible, and whale bones rather than seashells may haunt the shore. The setting is, however, generally more liberating and the body is energized: this is a place where the tourism industry is always overshadowed by nature and culture (where it exists). Pleasure is derived from being overwhelmed by, succumbing to and respecting the environment. Wide open vistas are everywhere. Souvenirs are indigenous and expensive. And the natives are - well, it may be difficult to assess their expression because they are covered head to foot in warm clothing - or, perhaps they don't even exist.

Whether qualifying as hot or cold, every island is unique. Yet, a comparative 'island studies' perspective alerts us to some of the underlying patterns lurking within the diversity of cold water islands, just as it has been doing for many years with its warm water counterparts (e.g.: Apostolopoulos \& Gayle, 2002; Conlin \& Baum, 1995; Finney \& Watson, 1977; Harrison, 2003), apart from the obvious pronouncement that the water is usually too cold for swimming. Cold water island locations tend to have harsh as well as pristine and fragile natural environments, characterized by wide open spaces and low populations at best. They become contexts for an exceptional and expensive form of vigorous, outdoor, adventure or cultural tourism, and direct encounters with nature (observing penguins, bears or wild flowers; hunting wild game; visiting parks); history (whaling stations, abandoned mines, battle sites, research stations, explorer routes); and local culture (indigenous people, their lifestyle and artifacts): definitely not places to laze about and relax in hotel precincts. Indeed, there may not even be a hotel. The locals, where they exist, are not particularly enthusiastic about visitors; few of the locals owe their livelihoods to tourism anyway, and they are usually in agreement that visitor numbers must remain low - and especially so if the locals happen to be a bunch of scientists. Specific local interests - a company, a monastery, a corporation, apart from the scientific community - can have inordinate influences on local public policy, since there is a tighter, more compact and more identifiable resident elite. This acts to brake increases in visitations, since there is no grassroots, democratic pressure to do so (Baldacchino, 2006b: 9-10). The anomaly in our set remains Iceland, since 1944 the world's coolest sovereign state and the world's only 'cold-water', small island state (more on this below). For a cold water island, it has by far the largest population, the highest tourism numbers and the strongest tourism infrastructure in the world - which, by the way, includes one small, geothermically heated beach at Nauthólsvik.

\section{A Late Development}

Cold water island tourism destinations could be seen as "counter-places" in comparison to warm water ones (Gössling \& Wall, 2007). They seem to have only been discovered of late by tourism 
researchers. In Conlin \& Baum (1995), a typical text on island tourism, only one out of the nine chapters dedicated to 'management practice' deals with a 'cold water' location (Corner Brook, in Newfoundland). Out of 93 different islands or island regions listed in its index, only five at most could be considered as 'cold water' ones (Antarctica, Falklands, Newfoundland, New Zealand and Prince Edward Island). Briguglio et al. (1996a, 1996b) are landmark volumes on island tourism issues, but only one out of 29 chapters deals with a cold water location - by Butler on the Shetlands (Butler, 1996). Lockhart \& Drakakis-Smith (1997) do somewhat better: three (opening) chapters address themes largely relevant to islands beyond the tropical 'pleasure periphery'. However, once the text goes into case study mode, only 3 out of 14 chapters are not sourced from warm climes: Butler (again) on Orkney \& Shetland (Butler, 1997); Royle on the South Atlantic Islands, which includes the Falklands (Royle, 1997); and Aronsson on Swedish islands (Aronsson, 1997). Gradus \& Lithwick (1996) and Krakover \& Gradus (2002), in spite of promising titles that highlight frontier regions, do not discuss islands at all. Jan Lundgren (2001) does the same: his brief prologue - on tourism destination development in extreme locations does not address islands. A paper and then a monograph on cold water tourism in the North Atlantic appeared in 1993 and 1998 respectively (Baum \& Hagen, 1993; Hagen-Grant, 1998); and this was developed into a book chapter on 'cold water island tourism' a year later (Baum et al., 2000).

There is great irony in the neglect of cold water islands, since the physical evidence is skewed in the other direction. If one takes islands to be pieces of land permanently surrounded by water with a land area of at least $0.1 \mathrm{~km}^{2}$, then the distribution of islands according to latitude shows that most of them are located in the temperate zone of the northern hemisphere. The highest island density occurs between latitude $50^{\circ} \mathrm{N}$ and $80^{\circ} \mathrm{N}$ (precisely where there is the least amount of ocean), and a sharp peak within that band occurs between $58^{\circ} \mathrm{N}$ and $66^{\circ} \mathrm{N}$ (see Map 1 ).

At those latitudes, the density of islands of about 30 per $10,000 \mathrm{~km}^{2}$ is ten times higher than anywhere else. Most of these islands are located along the coasts of mainlands, creating a patchy landscape made of tiny islands separated by narrow channels. The Åland Archipelago: a puzzle of 3,000 patches of islands and islets over a surface of $15,000 \mathrm{~km}^{2}$ in the Baltic Sea, creates the world's highest density of islands: 1,763 islands per 10,000 km² (Depraetere \& Dahl, 2007).

Perhaps one is excused for assuming that the typical island is located in the tropics, and is therefore warm, since it is precisely thanks to the marketing juggernaut of the tourism industry that such perceptions have become a common occurrence today. Moreover, if it is in the interest of states and governments to promote tourism to their island or archipelago, then we should also keep in mind that 42 out of the 43 sovereign states of the world are exclusively island or archipelagic states located in tropical or temperate zones (Baldacchino, 2006a; CIA, 2006). 


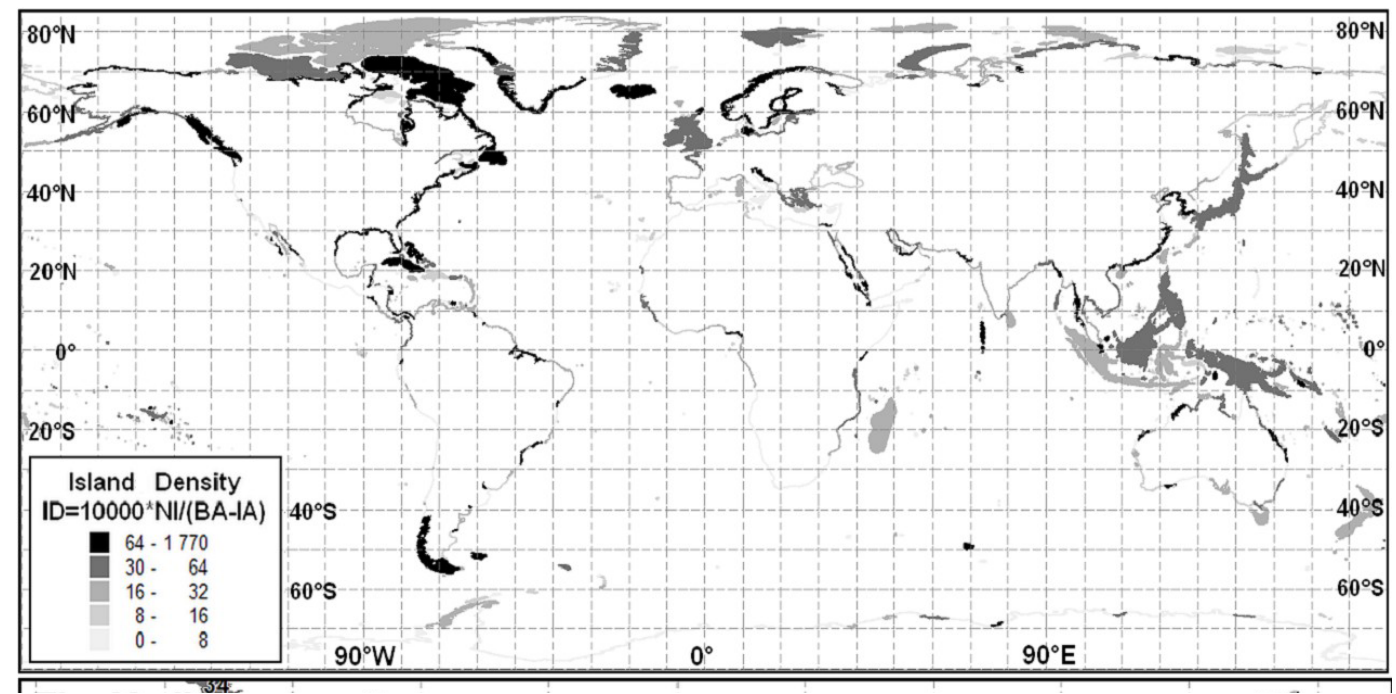

Map 1: Distribution of Islands around the World. (Courtesy of Christian Depraetere.)

There are more cold water locations among the world's sub-national island jurisdictions (places like Åland, Falklands, Faroes, Greenland, Shetland), but these do not typically utilize their 'paradiplomatic efforts' (e.g. Aldecoa \& Keating, 1999) to advance their tourism industry. Moreover, these can often depend on domestic tourists and carriers (such as Danes for Greenland; Swedes and Finns for Åland). There is only one exclusively cold water sovereign state: Iceland. In fact, as an indirect confirmation of the power of jurisdiction in promoting tourism, Iceland is the island that probably receives the largest number of cold water tourists per annum: some 320,000, plus 60,000 cruise ship visitors (Gössling, 2006). Yet, compare this to annual tourist arrivals to other islands: 1 million to Guam, 1.2 million to Malta, 2.3 million to Cyprus, 3.2 million to Puerto Rico, 7 million to Hawaii ... and to the highest penetration indices of tourists per indigenous population and land area in the insular Caribbean (Aruba, Cayman, British Virgin Islands, US Virgin Islands, Sint Maarten) - (McElroy, 2002; 2003; 2006).

The difference is clearly one of matched low tourist numbers (demand) and low tourism capacity (supply. Greenland, the world's largest 'island' ${ }^{1}$ with a sprawling land mass of over 2 million $\mathrm{km}^{2}$, receives just 30,000 tourists annually. This is not difficult to explain: most visitors come to cold water islands on small vessels or on small planes after long haul flights that deter all but the strong-willed and affluent. They may get off their vessels on zodiacs, braving the waves, cold winds, ocean spray and ice floes, and spend just a few hours on shore, under the watchful eye of scientists, expert guides or locals, just in case they wander away, do something foolish, or threaten to damage the fragile ecosystem. There may be no hotels or restaurants, and visitors (for those staying more than a day) may have to stay with locals. Moreover, more or better tourism infrastructure - such as roads, docks, airports, hotels, bars, casinos and restaurants - are less likely to be set up, or be improved, since there are few permanent residents, or none at all, to stimulate demand. In contrast, strong vested local interests commercial, scientific, political or religious - can easily conspire to prevent any such suspicious trappings of modernity from materializing, a policy stance more easily maintained because the

\footnotetext{
${ }^{1}$ Although, should its thick ice sheet melt, most of Greenland (like Antarctica) would not be above sea-level.
} 
significance of tourism to the domestic economy is usually small. The tourism 'footprint' is therefore much less significant on cold water islands, even though the potential damage which even that may cause to the environment is larger. However, the value added per tourist is greater, and the opportunity for this tourist to connect with nature or indigenous people (where they exist) is also much higher, providing a different sense of satisfaction.

Table 1: Cold Water and Warm Water Islands: Tourism Data Comparisons (Courtesy of Jerome L. McElroy)

\begin{tabular}{|c|c|c|c|c|c|c|}
\hline & Population & $\begin{array}{l}\text { Land area } \\
\left(\mathrm{km}^{2}\right)\end{array}$ & $\begin{array}{c}\text { Tourists } \\
\text { per annum (day } \\
\text { visitors) }\end{array}$ & Rooms & Room $/ \mathrm{km}^{2}$ & Vis/Pop \\
\hline \multicolumn{7}{|l|}{ COLD WATER ISLANDS } \\
\hline Nunivak (Alaska) & 180 & 4,210 & 250 & $20^{*}$ & 0.005 & 1.39 \\
\hline Banks (Canada) & 160 & 67,340 & 50 & 10 & 0 & 0.31 \\
\hline Baffin (Canada) & 17,000 & 507,450 & 33,000 & 290 & 0 & 2 \\
\hline Greenland & 57,000 & $\begin{array}{l}\text { 410,000 (ice- } \\
\text { free) }\end{array}$ & 30,000 & 425 & 0.001 & 0.53 \\
\hline Iceland & 297,000 & 103,000 & $836,000(45,000)$ & 7,490 & 0.073 & 2.84 \\
\hline Svalbard (Norway) & 2,600 & 62,000 & $\begin{array}{l}27,200 \text { cruise } \\
\text { tourists }\end{array}$ & 331 & 0.005 & 1.46 \\
\hline Luleå (Sweden) & 80 & 10,000 approx. & 1,000 & $25^{*}$ & 0.003 & 12.5 \\
\hline Solovetsky (Russia) & 1,000 & 290 & 30,000 & 60 & 0.207 & 30 \\
\hline Falklands (UK) & 2,500 & 12,000 & 50,000 & 25 & 0.002 & 20 \\
\hline Macquarie (Australia) & 0 & 43 & 400 & 0 & 0 & 0 \\
\hline Stewart (New Zealand) & 400 & 1,746 & 60,000 & 250 & 0.143 & 150 \\
\hline Chatham (New Zealand) & 700 & 2,500 & 500 & 20 & 0.008 & 1.1 \\
\hline South Shetlands \& Antarctica & 0 & 40,000 approx & 27,000 & 0 & 0 & 0 \\
\hline \multicolumn{7}{|l|}{ WARM WATER ISLANDS } \\
\hline St. Maarten & 38,000 & 41 & $475,000(1,348)$ & 4,000 & 96 & 17.47 \\
\hline Cayman Islands & 44,000 & 260 & $260,000(1,693)$ & 5,127 & 20 & 11.3 \\
\hline Turks and Caicos & 21,000 & 430 & 170,000 & 2,500 & 6 & 8.1 \\
\hline Malta & 399,000 & 320 & $1,158,000(292)$ & 19,885 & 62 & 3 \\
\hline Antigua & 69,000 & 440 & $245,000(523)$ & 3,185 & 7.2 & 4.61 \\
\hline Maldives & 349,000 & 300 & $617,000(4)$ & 8,747 & 29 & 1.8 \\
\hline Seychelles & 81,000 & 455 & $121,000(7)$ & 2,477 & 5.4 & 1.51 \\
\hline Polynesia & 271,000 & 3,660 & 212,000 & 3,326 & 0.91 & 0.78 \\
\hline Samoa & 177,000 & 2,850 & 98,000 & 950 & 0.33 & 0.55 \\
\hline Cape Verde & 418,000 & 4,030 & 157,000 & 3,150 & 0.78 & 0.38 \\
\hline Reunion & 777,000 & 2,500 & 430,000 & 2,904 & 1.16 & 0.55 \\
\hline Comoros & 671,000 & 2,170 & 18,000 & 375 & 5.8 & $\begin{array}{l}0.03 \\
\end{array}$ \\
\hline
\end{tabular}

*Author's estimate

Rooms: Beds/2 or \# of guesthouses X 10

Vis/Pop: \# tourists + 0.14 X \# Day Visitors/ population

The clear contrast between a sample of cold water islands (Baldacchino, 2006c) and that of tourist penetrated warm water islands is evident from Table 1. Most warm water islands have levels of tourism penetration and infrastructure that are many times higher than those of their 


\section{G. Baldacchino}

cold water cousins, whether in terms of beds, tourist numbers or just space. Cold water islands may have more empty space, but the number of local residents is low. Consequently, the economic impact of tourism can be felt even with low figures, while the environmental and social impacts may remain insignificant. Finally, many warm water destinations are sovereign states in themselves; all cold water destinations (excluding Iceland) are not. Thus, tourism infrastructure in warm locations has to live side by side with resident populations (except in such extreme situations as the Maldives which practise archipelagic zoning), who may resent the high tourist presence: it is difficult to imagine an "irritation index" (or irridex) emerging from cold water island research (Doxey, 1975; 1976). And yet, islanders would prefer to have a piece of the tourist action, readily applying pressure on the accessible and transparent 'soft state' (Hyden, 1983) to see to that, all the more so if in a pluralist democratic framework. This may explain why it is so easy to adopt a more 'mass' tourism market driven strategy in tourism destinations which are, concurrently, bases for locally elected governments.

The difference in numbers and capacity is, in turn, the effect of a 'double-punch' of cost and distance. Difficulty of access and limited tourism infrastructure means that only small scale vessels or planes can make land. Absence of economies of scale means that the trip to the cold water location is a long and expensive one. For 'cold water' travellers, the trip is often experienced as an integral part of the journey, and not just a necessary distraction - and especially so if it is on a boat, rather than a plane.

Tourism in warm water islands also started from a very narrow base. There, the industry in most cases just grew, mainly because many of the locals perceived that there were benefits to be enjoyed by plugging into the industry for secure all-round employment, seasonal part-time work or self-employment. Meanwhile, governments encouraged the development of tourism infrastructure, often seeking to lure foreign investment and identifiable brands. Today, the insular Caribbean, the most tourism branded and penetrated region in the world, has most of its shorefront controlled or owned by hospitality interests or expatriates. The pressure on public infrastructure (roads, electricity, sewage, water, parking) is immense; the associated environmental issues (air, sea and noise pollution) just as challenging. The leakages from the domestic economy - via foreign air lines, foreign travel agents, foreign hotel chains, imported cars, food, furniture and gas - are considerable. The price of property has reached dizzy heights, ushering in a process of 'gentrification' (Clark, 2005) that may crowd out the locals from the housing market, starting, but not stopping, with the poorest.

To such problems of non-sustainabilitycan be added other disadvantages: resorts are transformed into sanitized, clearly gated and secured enclaves; locals are stereotyped (often with racist overtones) as happy, pleasure-seeking, lazy and inferior, catering to the leisure requirements of the visitors; a local resentment is fuelled by the parading contrast of foreign affluence and indigenous poverty (Dann, 2006: 27). Tensions can be high and can erupt in conflict (Cambers et al., 2002).

Except for the unplanned consequences of global warming, tourism in cold water islands is not likely to experience the same spurt of growth. Temperature, and difficulty and cost of access, will keep the numbers down where the local authorities wish to keep them. Fortunately, at their 
early position in the resort life-cycle, they have ample time and room to plan a sustainable industry.

\section{Emulating Cold Water Islands: 3 Examples}

Have any 'warm water' islands be able to buck the trend to a mass market and in this way emulate their 'cold water' cousins? Yes: there are a few examples which suggest a fairly successful brake on the normal expansion of tourism and its creeping penetration on a small island's infrastructure, economy and society.

The Seychelles may be one such example. This has been one of the most stable, fastest growing economies in Africa over the medium term, having made a successful transition to democracy in the last decade. The arrival of 130,000 tourists generated US\$112 million in 2000, corresponding to $20 \%$ of GDP and $60 \%$ of foreign exchange earnings (Shah, 2002). The same number of visitors was reported for 2005. McElroy (2006b) assigns it a penetration index of 0.107. Tourism is thus a key pillar of the economy for this 112-island archipelago with a population of around 90,000. The Seychelles has adopted a strong-arm approach to the industry. It has limited the size of hotels (beyond tourism 'villages') to a maximum of 200 rooms; it maintains a selective marketing approach where pricing acts as a filter for the type of tourism that the country desires. It has realized that its furthermost tourist destinations - like Bird Island and Cousin Island - have higher occupancy rates, even though they are costlier and both more difficult and expensive to get to. Prices per bed night per person reach $€ 40$, even in the simplest guesthouses (e.g. Rosalie, 2002).

Environmental legislation in the Seychelles was implemented in a top-down process under the one-party state of President France Albert René in the mid-1970s. This policy continued even after the turn to democracy in the early 1990s. The institutional framework for environmental conservation was established with the implementation of the Department of the Environment in 1989. As early as 1990, this Department presented the first environmental management plan for the Seychelles (RoS, 1990), followed by a plan for 2000-2010 which provides guidelines for all activities related to the environment (RoS, 2001). In order to ensure environmental conservation, some $50 \%$ of the land area of the Seychelles $\left(230 \mathrm{~km}^{2}\right)$ was turned into protected areas (RoS, 2001). These areas are of particular importance in creating the image of an ecoisland, and they are part of the Seychelles' successful marketing strategy (Gössling \& Wall, 2007). Within the archipelago, such an island as Aldabra, a UNESCO World Heritage Site, has no permanent settlement and is only accessible to scientists and special visitors.

Another example of successful containment and high value added could be that of $\underline{\mathrm{St}}$ Barthélemy (or St Barths), a Caribbean island which forms part of the French departément d'outre mer of Guadeloupe. The island has an area of only about $12 \mathrm{~km}^{2}$ and a residential population of about 3,500 persons. Doumenge (1998: 341) describes the island as follows:

"There, the airport has a very small airstrip, accessible only to small planes having not more than 20 seats (including that of the pilot). This drastically limits tourist access, and offers an efficient means of control. In St Barthélemy, you can enjoy a very quiet, traditional way of life, with a very high standard of living, and the 


\section{G. Baldacchino}

islanders control their destiny in a more thorough manner than would otherwise be possible”.

For the insatiably curious, the island's “incredibly short runway” (Insiders' Guide, 2006) is 2,100 feet long (646 metres). (In the Caribbean region, only Saba has as shorter runway.) Flying on a scheduled flight into St Barths is only possible with small planes like the 20-seater Hawker de Havilland Twin Otter.

A total of 175,055 passengers arrived in St Barths in 2003, port and airport combined: "passengers" includes both residents and visitors alike, since there is as yet no system that allows the exact number of tourists to be counted - the number of visitors is thus around 50,000 (the large majority being American) (St Barths News, 2004). It is not possible to fly direct into St Barts: the main entry point for commercial flights is via Dutch Sint Maarten, just 10-minutes' flying time away. Those ten minutes, apparently, make a world of a difference. As Doumenge (ibid.) candidly continues:

"Just in front of St Barthélemy lies Sint Maarten, an island with disaster written all over it, with its mafia barons, gambling racket, and crowds in excess of one million tourists a year channeled through a large international airport.”

A third example of how the containment policy can run into serious difficulty, even though it may have started off with the best of intentions, concerns the Galápagos Islands. This island archipelago has been identified as “Evolution's Workshop” following the pioneering work of such bio-geographers and zoologists as Charles Darwin, David Lack and Peter \& Rosemary Grant (Larson, 2001). One-third of the archipelago's vascular land plants are endemic, as are nearly all the reptiles, half the breeding land birds, and almost 30\% of the marine species. This has led to an international movement to preserve the islands' unique ecosystem, and the support of the Ecuadorian Government, to which the islands belong. The plan was that controlled tourism would help safeguard the rich flora and fauna, while sustaining livelihoods for the locals. The Charles Darwin Research Station, run by the Charles Darwin Foundation, was set up in 1959 (www.darwinfoundation.org/); UNESCO declared the Galápagos one of its first four World Heritage Sites in 1978; a Biological Marine Resources Reserve was set up in 1986, with a zoning plan in place by 1992; and a 1998 'Special Law' restricted movement of mainland Ecuadorians to the islands. It looked like the environmentalists had secured the upper hand in the context of a positive-sum game (UNEP/WCMC, 2006).

But the experience has proved exasperating. Hoping to find work, and lured by the prospects of a better life, people from mainland Ecuador have literally invaded the Islands. The 1949 population was just 800. The 1990 Census reported an island population of 9,735. In 2005, the resident population was 28,000, and is growing at $6.5 \%$ per annum. Tourism has been too successful: despite high prices - the National Park charges a US\$100 entrance fee on foreign tourists - the stream of visitors has never wavered. In the 1960s, there were around 1,000 tourists annually; some 100,000 visitors are expected in 2006. A second airport has been built and a third one is under discussion. There is now talk of cruise ship visitation.

Over-fishing or illegal fishing has become a major issue. When migrants do not find work in tourism, they often find jobs in the fishing industry. The sea cucumber and sharks of the 
Galapagos have become alarming targets, since both are very popular in Asian markets for their aphrodisiac or medicinal qualities and fetch good prices. When a decree banned all fishing of sea cucumbers in the Galapagos because of dwindling stocks, fishers protested violently. Although the ban has been replaced by a quota, there have been continuous strikes on the part of the fishermen. As recently as April 2004, angry fishers besieged the Charles Darwin Station and demanded the right to use greater nets and longer lines (Galápagos Islands web-site, 2006).

The Galápagos Islands is a case study of the weakness of governmental resolve in the face of overwhelming public pressure, and in defiance of international concern. Existing laws do not appear to be enforced. The continuing flow of mainlanders migrating into the islands increases domestic pressure to exploit, rather than preserve, natural resources; increases the presence and impact of invasive species (feral goats, cats, mice, rats, cattle, plants) which ravage the ecosystem (e.g. McKie, 2006); increases local interest in continuing to grow tourist visitations; and brings the $21^{\text {st }}$ Century ever so much closer to the place, with all its consequences. National Geographic used photographs of newly paved streets and mounting garbage in its millennium feature, titled "Paradise in Peril" (Benchley, 1999); and a tanker carrying fuel oil ran aground early in 2001, fouling Galápagos waters (Larson, 2001: 236). The number of visitors (which includes some 25,000 Ecuadorians annually) may have outgrown the ability to protect against their impact. A thousand miles of ocean to the nearest land, plus high prices of travel and accommodation, have not provided enough of a deterrent to stabilize tourism.

\section{Discussion}

\section{Differences}

Cold water islands, from both northern and southern hemispheres, differ widely in size, population, tourism penetration or tourism capacity (see Table 1). They range from Greenland (population 55,000, over 410,000 $\mathrm{km}^{2}$ of ice-free land), and Iceland (population 300,000, 103,000 $\mathrm{km}^{2}$ ); to tiny Macquarie Island in Australia (population = zero; $34 \mathrm{~km}^{2}$ ), Banks Island in the Canadian Arctic (population 153; 67,340 $\mathrm{km}^{2}$ ), and the 742-island Luleå Archipelago in Sweden (population 80). They also exhibit a variety of distinct traditions including, among others, the Inuit culture in Baffin Island, Canada, Viking history across the North Atlantic Islands, and the Maori muttonbird harvesting in Stewart Island, New Zealand. Most are recently emerging as international destinations. Some have no airports. Few have cruise liner terminals. Visitor numbers are as little as 500 a year on Macquarie Island and Nunivak Island; there are only 50 hotel rooms in the Falklands and two hotels on Chatham Island; and there is absolutely no dedicated tourism infrastructure in Antarctica. Other destinations do better: Baffin (Nunavut), Greenland, Stewart, Svalbard and Solovetsky attract some 30,000-60,000 annual stay-over or cruise visitors each.

\section{Similarities}

In spite of these differences, these cases possess a range of similarities. Their assets include isolation (ironically), unusual terrestrial and marine wildlife and scenery, unique geologic and atmospheric features and ample opportunity for adventure holidays (such as hunting, fishing, dog-sledding) and cultural experiences - all of which are inherent to the place. They appeal for 


\section{G. Baldacchino}

active leisure, as well as to rather mature tourist types. They illustrate the constraints on tourism development imposed by climate-induced seasonality and difficult and expensive access. They each have a distinct, differentiated product - not easily subsumed under a generic label, and therefore not operating in direct competition with other cold water locations (as many warm water islands find out about themselves, to their cost). (This recognition perhaps explained why they have not been seen as 'cold water islands', in a collective sense.) They also represent (with the exception of Iceland and Antarctica) small-island economies undergoing tourism diversification in the face of declining traditional sectors (mining, fishing, agriculture). Many face the similar challenges of determining destination identity, enabling the small-scale ecotourism attractions compatible with that native natural and cultural "genius of the place," and establishing the infrastructure and facilities to access them. Unlike Iceland (which may, in coming decades, need to begin seriously managing visitor densities), these destinations are in the initial stages of visitor marketing and promotion to establish international visibility (McElroy \& Potter, 2006; Butler, 2006).

\section{Political Geography Insights}

One interesting set of similarities relates to the political geography of the tourism industry in these cold water islands. This factor might partly explain why there are less pressures to expand tourism on these locations.

Extreme island regions tend to lie on the political periphery, especially when they have small populations: un/under-represented in the corridors of power; largely forgotten by centralized policy makers suffering from 'the urban bias'; dismissed as insignificant backwaters other than, perhaps, in strategic (military and resource) terms (Butler, 1993; Wilkinson, 1994). A weak local political influence and a lackadaisical interest from the centre do, in turn, suggest that local elites assume significant politico-economic power. These elites also tend to be narrower, less fragmented and more concentrated in island jurisdictions with small populations (e.g. Buker, 2005; May \& Tupouniua, 1980; Richards, 1982). Moreover, in non-sovereign island territories, the concentration of local politico-economic power is more likely to lie in the hands of a small identifiable group: a religious congregation (Solovetsky), a team of scientists (Macquarie); an indigenously controlled corporation (Nunivak; Baffin); an arms-length enterprise trust (Chatham); or a municipality (Luleå). Antarctica has its own, unique, multi-lateral governance regime, which transcends national territorial sovereignty, and is primarily driven by scientific interests. Such skewed influence creates a situation where there is hardly a plurality of interest groups clamouring to benefit, and benefit fast, from the tourism bandwagon. The oligopolies in power are champions of tradition; they effuse caution and harbour a suspicion of change. They are aware of the environmental and economic risks of mass tourism. There is limited discussion on whether to take the industry forward. Most have no stake in tourism - which is not a key industry anyway - and so are more likely to view its potential with some grave concerns. This is well captured in the following statement, uttered by none other than Archimandrite Josef, Solovetsky Monastery representative. It leaves no room for any discussion:

"[O]vergrowth of tourism flows and preservation of divine spirit of the island are incompatible. Nobody even thinks of converting Solovetsky into a trendy resort where the White Sea shore is full of restaurants and ... the sky above the Monastery's towers is 
crossed by para-gliders” (International symposium, Solovetsky: Future Insights, 2003; quoted in Nevmerzhitskaya, 2006: 162).

The situation may be different where you have two or more centres of power with divergent views about the future of tourism: this appears to be the case in the more developed, more populated, territories, where tourism plays a more important economic role. In Svalbard, where the local entrepreneurs wish to expand tourism, it is the Governor who is less keen; meanwhile, Iceland is encouraging an increase in tourist visitations. There is thus an uncanny similarity to the situation in the Seychelles, which developed the foundations of its tourism strategies in a top-down fashion, and during a period of one-party rule. Meanwhile, both the Seychelles and St Barths have transformed what might at first glance appear to be a trinity of awesome physical obstacles (remoteness and archipelagicity on one hand; a small airport runway on the other) into tools which help to filter and control access, increasing the distinctiveness - and maintaining a relatively high price - for the tourism experience.

\section{Conclusion}

What therefore seems to happening is that low populations, challenging infrastructure and logistics, plus 'enlightened governance' conspire to maintain a few warm water islands in a niche of envious exclusivity. This creates possibilities for sustainable, low volume, but high value added per capita tourism, with less strain on infrastructure and resource needs. The product is also differentiated from the more competitive, mass, warm water tourism market, where individual island attributes tend to be glossed over, and where price is the all important determiner of demand and supply.

Cold water islands inadvertently play a similar game - not so much as the outcome of a deliberate strategy, but because of the 'double-punch' of cost and distance, maintained and safeguarded, in some cases, by wary, conservative, local political elites. In spite of the democratic deficit that may prevail in such locations, the evidence suggests that it is perhaps necessary to be "cruel in order to be kind". Sound, strategic, long-term local (albeit perhaps authoritarian) management, narrow but deep civilian 'buy in', and an absence of pluralism in political life, can conspire with climate and relative inaccessibility to limit tourism to a small scale, low-impact industry with a relatively high, locally retained value added (e.g. Butler, 1997: 78).

\section{Acknowledgements}

My thanks to Lino Briguglio and the Islands \& Small States Institute at the University of Malta, Malta, for inviting me to the sustainable island tourism conference held in May 2006 where I presented an earlier draft of this paper. My thanks also to Graham M.S. Dann, Stefan Gössling, Jerome L. McElroy, Stephen A. Royle and E. Kathleen Stuart for useful, critical comments on earlier drafts. I am also grateful to Mark Hampton, Centre for Tourism in Islands and Coastal Areas, Kent Business School, University of Kent at Medway, UK, for inviting me to deliver the Centre's inaugural address in October 2006, with a presentation based on this paper. A version of this paper was also delivered to tourism students and faculty at the Buxton Campus of the 
University of Derby, UK. Table 1 has been kindly compiled by Jerome L. McElroy. Map 1 is courtesy of Christian Depraetere and will appear in Baldacchino (ed.) 2007.

\section{References}

Aldecoa, F. \& Keating, M. (eds.) (1997) Paradiplomacy in Action: The Foreign Relations of Subnational Governments, London, Frank Cass.

Apostolopoulos, Y. \& Gayle, D.J. (eds.) (2002) Island Tourism and Sustainable Development: Caribbean, Pacific, and Mediterranean Experiences, Westport CT, Praeger.

Aronsson, L. (1997) 'Tourism in Time and Space: An Example from Smogen, Sweden’ in D.G. Lockhart \& D. Drakakis-Smith (eds.) Island Tourism: Trends and Prospects. London, Pinter, pp. 118-136.

Baldacchino, G. (2006a) 'Islands, Island Studies, Island Studies Journal', Island Studies Journal, Vol. 1, No. 1, pp. 3-18. (Available from: www.islandstudies.ca/journal).

Baldacchino, G. (2006b) 'Editorial Introduction' in Extreme Tourism: Lessons from the World's Cold Water Islands, Oxford, Elsevier, pp. 3-14.

Baldacchino, G. (ed.) (2006c) Extreme Tourism: Lessons from the World's Cold Water Islands, Oxford, Elsevier.

Baldacchino, G. (ed.) (2007) A World of Islands: An Island Studies Reader, Malta \& Canada, Agenda Academic \& Institute of Island Studies, forthcoming.

Baum, T.G. \& Contributors (2000) 'Tourism and Cold Water Islands in the North Atlantic' in G. Baldacchino \& D. Milne (eds.) Lessons from the Political Economy of Small Islands: The Resourcefulness of Jurisdiction. Basingstoke, Macmillan, pp. 214-229.

Baum, T.G. \& Hagen, L. (1993) 'Responses to Seasonality: The Experiences of Peripheral Destinations’, International Journal of Tourism Research, Vol. 1, No. 5, pp. 299-312.

Benchley, P. (1999) 'Galápagos: Paradise in Peril', National Geographic, Vol. 195, No. 4, pp. 2-31.

Briguglio, L., Archer, B., Jafari, J. \& Wall, G. (eds.) (1996a) Sustainable Tourism in Islands \& Small States: Issues and Policies, London, Pinter.

Briguglio, L., Butler, R.W., Harrison, D. \& Leal Filho, W. (eds.) (1996b) Sustainable Tourism in Islands \& Small States: Case Studies, London, Pinter.

Buker, P.E. (2005) 'The Executive Administrative Style in Prince Edward Island: Managerial and Spoils Politics' in L. Bernier, K. Brownsley \& M. Howlett (eds.) Executive Styles in 
Canada: Cabinet Structures and Leadership Practices in Canadian Government, Toronto, University of Toronto Press, pp. 111-131.

Butler, R.W. (1993) 'Tourism Development in Small Islands: Past Influences and Future Directions' in D.G. Lockhart, D. Drakakis-Smith \& J.A. Schembri (eds.) The Development Process in Small Island States, London, Routledge, pp. 71-91.

Butler, R.W. (1996) 'Problems and Possibilities of Sustainable Tourism: The Case of the Shetland Islands’ in L. Briguglio, R. W. Butler, D. Harrison \& W. Leal Filho (eds.) Sustainable Tourism in Islands \& Small States: Case Studies, London, Pinter, pp. 11-31.

Butler, R.W. (1997) 'Tourism in the Northern Isles: Orkney and Shetland' in D.G. Lockhart \& D. Drakakis-Smith (eds.) Island Tourism: Trends and Prospects. London, Pinter, pp. 59-80.

Butler, R.W. (2006) 'Epilogue: Contrasting Warm Water and Cold Water Island Tourist Destinations' in G. Baldacchino (ed.) Extreme Tourism: Lessons from the World's Cold Water Islands, Oxford, Elsevier, pp. 247-258.

Cambers, G., Muehlig-Hofmann, A. \& Troost, D. (2002) Coastal Land Tenure: A SmallIslands' Perspective, Wise Coastal Practices for Sustainable Human Development, UNESCO, www.unesco.org/csi/wise/tenure.htm.

CIA (2006) CIA World FactBook, Washington DC, Central Intelligence Agency, www.cia.gov/cia/publications/factbook/.

Clark, E. (2005) 'The Order and Simplicity of Gentrification: A Political Challenge' in R. Atkinson \& G. Bridge (eds.) Gentrification in a Global Context: The New Urban Colonialism, London, Routledge, pp. 256-264.

Conlin, M.V. \& Baum, T.G. (eds.) (1995) Island Tourism: Management Principles \& Practice, New York, John Wiley.

Dann, G.M.S. (2006) 'Promotional Issues' in G. Baldacchino (ed.) Extreme Tourism: Lessons from the World's Cold Water Islands, Oxford, Elsevier, pp. 15-30.

Depraetere, C. \& Dahl, A.L. (2007) 'Island Locations and Concentrations' in G. Baldacchino (ed.) A World of Islands: An Island Studies Reader, Malta \& Canada, Agenda Academic \& Institute of Island Studies, forthcoming.

Doumenge, F. (1998) 'Considerations for Small Island Development Today' in G. Baldacchino \& R. Greenwood (eds.) Competing Strategies of Socio-Economic Development for Small Islands, Canada, Institute of Island Studies, pp. 337-346.

Doxey G.V. (1975) 'A Causation Theory of Visitor-resident Irritants: Methodology and Research Inferences', Proceedings of the Travel Research Association, 6th Annual Conference, San Diego CA, pp. 195-8. 


\section{G. Baldacchino}

Doxey G.V. (1976) 'When Enough's Enough: The Natives are restless in Old Niagara', Heritage Canada, Vol. 2, No. 2, pp. 26-7.

Finney, B.R. \& Watson, K.A. (1977) A New Kind of Sugar: Tourism in the Pacific, $2^{\text {nd }}$ edition, Honolulu HI, East-West Center.

Galápagos Islands web-site (2006) 'Environmental Issues of the Galápagos', www.galapagosislands.com/html/environment.html.

Gössling, S. (2006) 'Iceland' in G. Baldacchino (ed.) Extreme Tourism: Lessons from the World's Cold Water Islands, Oxford, Elsevier, pp. 115-129.

Gössling, S. \& Wall, G. (2007) 'Island Tourism’ in G. Baldacchino (ed.) A World of Islands: An Island Studies Reader, Malta \& Canada, Agenda Academic \& Institute of Island Studies, forthcoming.

Gradus, Y. \& Lithwick, I. (eds.) (1996) Frontiers in Regional Development, Lanham MD, Rowman \& Littlefield.

Hagen-Grant, L. (1998) 'Seasonality in Tourism in the Small Islands of the North Atlantic', monograph, Canada, Institute of Island Studies, www.upei.ca/islandstudies/rep_lhg_1.htm.

Hall, C.M. \& Johnston, M.E. (eds.) (1995) Polar Tourism: Tourism in the Arctic and Antarctic Regions, Chichester, UK, John Wiley and Sons.

Harrison, D. (2003) Pacific Island Tourism, New York, Cognizant Communication Group.

Hyden, G. (1983) No Shortcuts to Progress: African Development Management in Perspective, London, Heinemann.

Insiders’ Guide (2006) ‘The Insiders’ Guide to St Barthélemy’, www.sbhonline.com/.

Krakover, S. \& Gradus, Y. (eds.) (2002) Tourism in Frontier Areas, Lanham MD, Lexington Books.

Larson, E.J. (2001) Evolution's Workshop: God and Science on the Galápagos Islands, New York, Basic Books.

Lundgren, J. (2001) 'Arctic Tourism Prologue' in B. Sahlberg (ed.) Going North: Peripheral Tourism in Canada and Sweden, Östersund, Sweden, Etour Publishers, pp. 9-12.

May, R. \& Tupouniua, S. (1980) 'The Politics of Small Island States' in R.T. Shand (ed.) The Island States of the Pacific and Indian Oceans: Anatomy of Development, Canberra, Australian National University, pp. 419-437.

McElroy, J.L. (2006a) 'Small Island Tourist Economies across the Lifecycle', Asia Pacific Viewpoint, Vol. 47, No. 1, pp. 61-77. 
McElroy, J.L. (2006b) Island Studies Resources - Island Tourism: A Database. Available at: www.islandstudies.ca/isresources.html.

McElroy, J.L. (2003) 'Tourism Development in Small Islands across the World', Geografiska Annaler, Vol. 85(B), No. 4, pp. 231-242.

McElroy, J.L. (2002) ‘The Impact of Tourism in Small Islands: A Global Comparison’ in F. di Castri \& V. Balaji (eds.) Tourism, Biodiversity and Information. Leiden, Backhuys, pp. 151167.

McElroy, J.L. \& Potter, B. (2006) 'Sustainability Issues' in G. Baldacchino (ed.) Extreme Tourism: Lessons from the World's Cold Water Islands, Oxford, Elsevier, pp. 31-40.

McKie, R. (2006) 'Darwin's Paradise in Peril', The Observer (UK), September 24 $4^{\text {th }}$, http://observer.guardian.co.uk/world/story/0,,1879630,00.html.

Nevmerzhitskaya, J. (2006) 'The Solovetsky Archipelago, Russia' in G. Baldacchino (ed.) Extreme Tourism: Lessons from the World's Cold Water Islands, Oxford, Elsevier, pp. 159-168.

Republic of Seychelles (RoS) (1990) Environmental Management Plan of Seychelles (EMPS) 1990-2000, Achieving Sustainable Development, Victoria, Mahé, Seychelles.

Republic of Seychelles (RoS) (2001) Environment Management Plan of Seychelles (EMPS) 2000-2010: Managing for Sustainability, Victoria, Mahé, Seychelles.

Richards, J. (1982) 'Politics in Small Independent Communities: Conflict or Consensus?', Journal of Commonwealth \& Comparative Politics, Vol. 20, No. 1, pp. 155-171.

Rosalie, M. (2002) 'Tourism and Social Development in the Seychelles', Development Bulletin, No. 60, November, pp. 95-98.

Royle, S.A. (1997) 'Tourism to the South Atlantic Islands' in D.G. Lockhart \& D. DrakakisSmith (eds.) Island Tourism: Trends and Prospects, London, Pinter, pp. 323-344.

Shah, N.J. (2002) 'Bikinis and Biodiversity: Tourism and Conservation on Cousin Island, Seychelles' in F. di Castri \& V. Balaji (eds.) Tourism, Biodiversity and Information, Leiden, The Netherlands, Backhuys, pp. 185-96.

St Barths News (2004) 'More Visitors in 2003 than in 2002', www.stbarths.com/editorials/cecil-lucot/04_03_06.html.

UNEP/WCMC (2006) ‘Galápagos National Park and Marine Reserve: Ecuador’, United Nations Environment Programme \& World Conservation Monitoring Centre, www.unepwcmc.org/sites/wh/galapago.html. 
Wilkinson, P.F. (1994) 'Tourism and Small Island States: Problems of Resource Analysis, Management and Development' in A.V. Seaton (ed.) Tourism: The State of the Art, Chichester, UK, John Wiley, pp. 41-51. 